\title{
Indicator bacteria community in seawater and coastal sediment: the Persian Gulf as a case
}

Vahid Noroozi Karbasdehi ${ }^{1}$, Sina Dobaradaran ${ }^{1,2,3^{*}}$, Iraj Nabipour ${ }^{4}$, Afshin Ostovar ${ }^{4}$, Hossein Arfaeinia ${ }^{5}$, Amir Vazirizadeh ${ }^{6}$, Roghayeh Mirahmadi ${ }^{1}$, Mozhgan Keshtkar ${ }^{1}$, Fatemeh Faraji Ghasemi ${ }^{1}$ and Farzaneh Khalifei ${ }^{1}$

\begin{abstract}
Background: The aim of present work was to assess the concentration levels as well as vertical distribution of indicator bacteria including total coliform, fecal coliform, Pseudomonas aeruginosa, and Heterotrophic Plate Count (HPC) in the marine environment (seawater and coastal sediments) and evaluate the correlation between indicator bacteria and some physicochemical parameters of surface sediments as well as seawaters.

Methods: A total number of 48 seawater and sediment samples were taken from 8 stations (each site 6 times with an interval time of 2 weeks) between June and September 2014. Seawater and sediment samples were collected from $30 \mathrm{~cm}$ under the surface samples and different sediment depths $(0,4,7,10,15$, and $20 \mathrm{~cm})$ respectively, along the Persian Gulf in Bushehr coastal areas.

Results: Based on the results, the average numbers of bacterial indicators including total coliform, fecal coliform, and Pseudomonas aeruginosa as well as HPC in seawater samples were 1238.13, 150.87, 8.22 MPN/100 ml and 1742.91 CFU/ $\mathrm{ml}$, respectively, and in sediment samples at different depths (from $0-20 \mathrm{~cm}$ ) varied between $25 \times 10^{3}$ to $51.67 \times 10^{3}, 5$. $63 \times 10^{3}$ to $12.46 \times 10^{3}, 17.33$ to $65 \mathrm{MPN} / 100 \mathrm{ml}, 36 \times 10^{3}$ to $147.5 \times 10^{3} \mathrm{CFU} / \mathrm{ml}$, respectively. There were no statistically significant relationships between the indicator organism concentration levels with temperature as well as $\mathrm{pH}$ value of seawater. A reverse correlation was found between the level of indicator bacteria and salinity of seawater samples. Also results revealed that the sediment texture influenced abundance of indicators bacteria in sediments. As the concentration levels of indicators bacteria were higher in muddy sediments compare with sandy ones.

Conclusion: Result conducted Bushehr coastal sediments constitute a reservoir of indicator bacteria, therefore, whole of the indicators determined were distinguished to be present in higher levels in sediments than in the overlying seawater. It was concluded that the concentration levels of microbial indicators decreased with depth in sediments. Except total coliform, the numbers of other bacteria including fecal coliform, Pseudomonas aeruginosa and HPC bacteria significantly declined in the depth between 10 and $15 \mathrm{~cm}$.
\end{abstract}

Keywords: Bushehr coastal, Indicator bacteria, Persian Gulf, Sediment texture

\footnotetext{
* Correspondence: s.dobaradaran@bpums.ac.ir;

sina_dobaradaran@yahoo.com

${ }^{1}$ Department of Environmental Health Engineering, Faculty of Health,

Bushehr University of Medical Sciences, Bushehr, Iran

${ }^{2}$ The Persian Gulf Marine Biotechnology Research Center, The Persian Gulf

Biomedical Sciences Research Institute, Bushehr University of Medical

Sciences, Boostan 19 Alley, Imam Khomeini Street, Bushehr, Iran

Full list of author information is available at the end of the article
}

(c) The Author(s). 2017 Open Access This article is distributed under the terms of the Creative Commons Attribution 4.0 International License (http://creativecommons.org/licenses/by/4.0/), which permits unrestricted use, distribution, and reproduction in any medium, provided you give appropriate credit to the original author(s) and the source, provide a link to the Creative Commons license, and indicate if changes were made. The Creative Commons Public Domain Dedication waiver (http://creativecommons.org/publicdomain/zero/1.0/) applies to the data made available in this article, unless otherwise stated. 


\section{Background}

Recreational water and beaches are often considered as a place where sensitive individuals may contact with microbial contaminations [1]. These areas are susceptible to fecal contamination from wastewater, septic leachate, farming drainage, livestock and domestic animals, or nonpoint sources of human and animal waste [2]. Fecal contamination in maritime areas can be dangerous to recreational users because feces may contain pathogenic microorganisms that can be ingested and bring intestinal problem [3]. Epidemiological surveys have revealed the positive relationship between fecal contamination at marine beaches and swimming-related diseases [4]. Microbial indicators have been utilized worldwide to show if a water body is contaminated by fecal contamination. Some of these indicators, i.e. fecal coliforms, E. coli and Enterococcus spp., are used to monitor the fecal contamination of seawater bodies worldwide [5]. Microbial impairment of drinking, irrigation, or recreational seawaters is generally monitored using concentration levels of fecal indicator bacteria [6]. But other bacteria including Pseudomonas aeruginosa, a gram-negative opportunistic human pathogen, and HPC bacteria may also be useful in defining seawater body quality [7]. Exceeding contents of indicator bacteria in seawater and sediments have been related to increased risk of pathogenic microorganism-induced sickness to humans [8]. Various researches have documented an elevated risk of contracting gastrointestinal diseases, skin infections as well as acute respiratory infections after exposure with recreational waters and seawater body with increased concentrations of indicator bacteria [9-12].

Within aquatic systems, it is highlighted that the indicator microorganisms can be highly related to the sediment fraction $[13,14]$. This relationship is due to four ecological performances of sediments; 1) provision a place for microbial attachment [15] serves as a favorable organic substance and nutrients for microbes [16], 3) protection from environmental stresses such as sunlight UV [17], protozoan grazing [18], etc., and 4) extracellular polymeric substances (EPS) of bacteria, which enhance sediment flocculation by coagulating and attaching particles together to create a floc matrix and in turn results in an increased downward flux of sediment [19] and accordingly connected bacteria (with potential pathogens) to the sediment [20]. In general, indicator bacteria can stay alive much longer in sediment than in the water column in both freshwater and maritime environments and many studies have confirmed this [21-24]. Pachepsky and Shelton [25] and Brinkmeyer et al. [26] observed significant correlations between fecal indicator bacteria in the seawater column and underlying sediments. They found that the levels of indicator bacteria in sediments considerably higher than seawaters. Koirala et al. also found that numbers of indicator organisms in sediments are greater than in water samples due to protection behavior of sediments [17]. There are some activities related to sediment resuspension in coastal areas such as commercial or recreational boating and storms that can lead to considerable effects on microbial loads of water [27]. In addition, recreational activity and wave action in the swash zone of the coast can also contribute to resuspension the bacteria from the sediment and consequently may predispose human to health risk [1]. Bushehr province with a long coastline (more than 707 kilometers) along the Persian Gulf and its strategic and geopolitical position, as one of the most important port, is located in southwestern Iran and northern part of the Persian Gulf (Fig. 1). Bushehr as energy capital in Iran is facing with industrial pollution in its marine environment [28] and its region is of special interest for environmental studies [29-33]. The climate is warm and wet in summer and mild in winter. Swimming in the Persian Gulf and playing in the coastline areas are the most important entertainments of people in the $\mathrm{Bu}$ shehr port. Also, there are sporadic studies on organism's concentrations in the coastal areas of the Persian Gulf but to our best knowledge there is no report yet on comprehensive and baseline data on indicator organisms profile in seawaters and sediments along the Persian Gulf. In this work for the first time in the region of the Persian Gulf, we aimed to (1) assess the concentration levels of indicator bacteria in different depths of surface sediments and seawaters as baseline information in the region (2) mapping and kriging interpolations of the microbial contamination in the surface sediments and seawaters (3) ascertain the correlation between indicator bacteria and some physicochemical parameters of surface sediments as well as seawaters.

\section{Methods \\ Chemicals and reagents}

The employed media including Lactose broth, Brilliant green, EC broth and $\mathrm{R}_{2} \mathrm{~A}$ agar media were prepared from Merck, Germany. The Asparagine broth and Acetamide broth media were prepared from SigmaAldrich, USA.

\section{Study area and sediment sample collection}

Seawater and sediment sampling were done between June and September 2014. A total number of 48 samples were taken from 8 sampling sites, including TV Park (S1), Skele-Jofreh (S2), Daneshjo Park (S3), Gomrok (S4), Skele-Solh Abad (S5), Skele-Jabri (S6), Bandargah (S7), and Shoghab (S8) (each site 6 times with an 
interval time of 2 weeks), which were located in the intertidal zone along the Persian Gulf in Bushehr beach zone (Fig. 1). First, seawater samples were collected from $30 \mathrm{~cm}$ under the surface (to avoid direct effect of sun ultraviolet radiation on the water surface layer) using a sterile $500 \mathrm{~mL}$ glass vessel (for bacterial analyses) and an open-mouthed bottle (for physicochemical parameters analysis). Next, surface sediments were collected from different depth (including 0, 4, 7, 10, 15 and $20 \mathrm{~cm}$ ) using an Ekman steel grab sampler $\left(25 \times 25 \times 25 \mathrm{~cm}^{3}\right)$. For each sampling sites, 2-4 sampling points were selected based on the place or shape, and samplings was carried out. The $\mathrm{pH}$ of each samples were measured in the place directly after sampling using a U-50 multi-parameter water quality checker (HORIBA, Germany). Samples were placed in a cold box (temperature roughly $4 \mathrm{C}$ and darkness) [34] and directly transported to the lab in coolers on ice within 2 hours.

\section{Media and procedures for bacterial analysis}

All microbial indicator analyses including total coliform, fecal coliform, Pseudomonas aeruginosa as well as HPC bacteria were done according to standard methods [34]. Lactose broth, EC broth and asparagine broth were employed to determine the most probable number (MPN) per $100 \mathrm{ml}$ of total coliforms, fecal coliforms, as well as Pseudomonas aeruginosa respectively, using a five-tube multiple-dilution technique. $\mathrm{R}_{2} \mathrm{~A}$ agar was used to ascertain the colony forming unit (CFU) per ml of HPC bacteria, using the spread plate technique. In the case of sediment samples, sediments were mixed thoroughly and diluted 1:10 with sterile distilled water $(1 \mathrm{~g}$ of sediment added into $9 \mathrm{ml}$ of sterile distilled water). This mixture was centrifuged with a speed of $8000 \mathrm{rpm}$ for 1-2 min and then was left to stand for 5-10 $\mathrm{min}$ to allow big particles to settle. Sediment suspensions were subsequently processed by the similar procedures as for water samples.

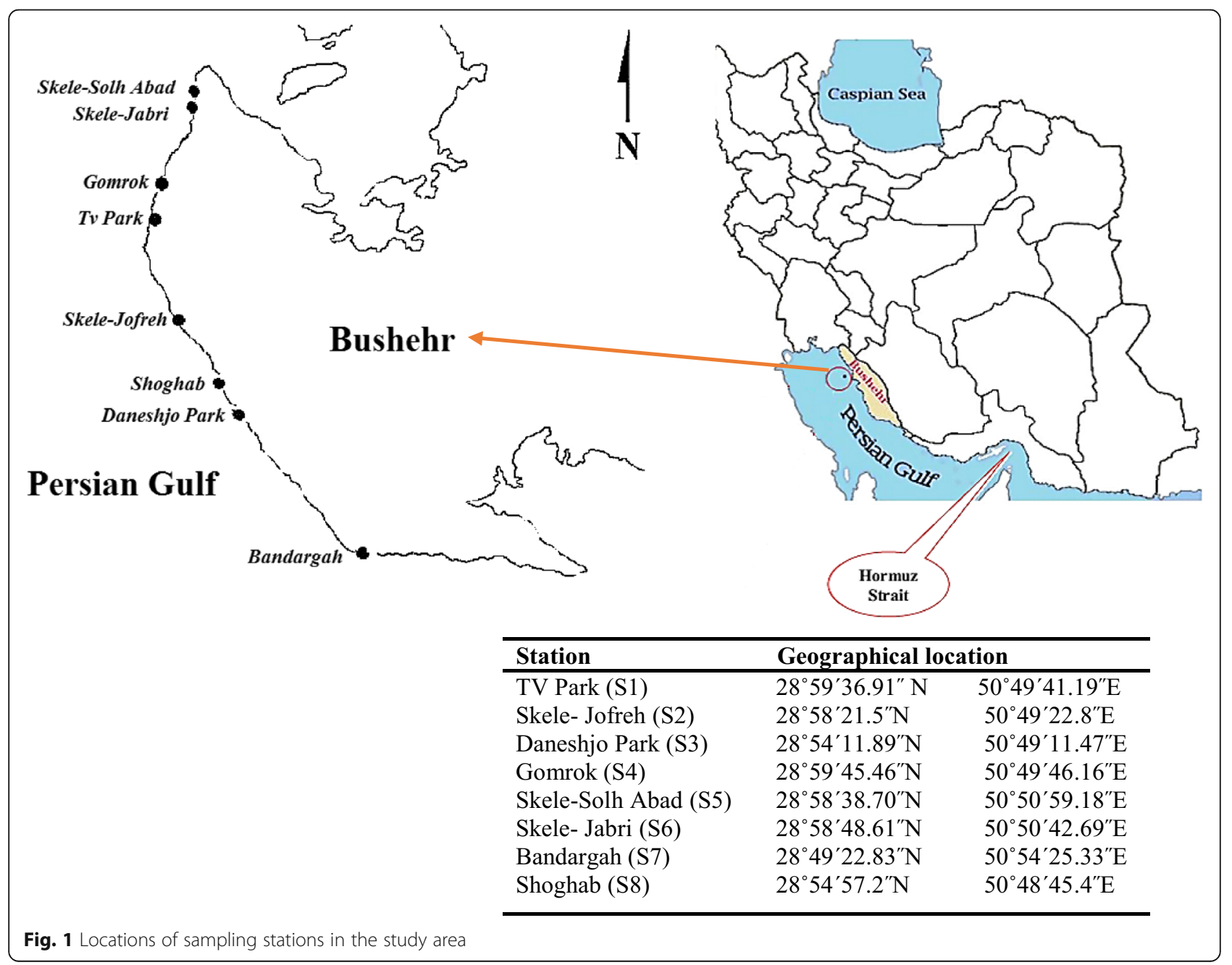




\section{Grain size analysis of sediment samples}

Sediment samples were collected by a grab sampler and coning and quartering technique was used to prepare sediments for grain size analysis [35]. Coning and quartering method involves five steps including: (1) pour the samples onto a flat surface to form a cone (2) flatting the cone (3) divide cone in half (4) divides halves into quarters and discard alternate quarters (5) two quarters are retain and mix together, reform cone and repeats steps until remaining sample be in a correct amount for analysis). After 5 cited steps, sediment sample was kept in a polythene bag labeled with number and location and transferred to the laboratory by cold box and stored in the freezer at $-20{ }^{\circ} \mathrm{C}$ until grain size examination according to Buchanan's method [36]. For analysis, sediment dried for 24 hours at $70{ }^{\circ} \mathrm{C}$ in Heraeus oven (UT 6420 model). 25 grams of dried sediment of each sample were put in a flask containing $250 \mathrm{ml}$ of distilled water. Then $10 \mathrm{ml}$ of 2.6 grams per liter of sodium hexametaphosphate $\left[\mathrm{Na}\left(\mathrm{PO}_{3}\right)_{6}\right]$ solution was added to the flask contents. After stirring the solution three times, each time for nearly 15 minutes, it was kept in the laboratory for 24 hours. In order to dry, the solution was placed in chines plates and then moved to the oven at $70{ }^{\circ} \mathrm{C}$ for

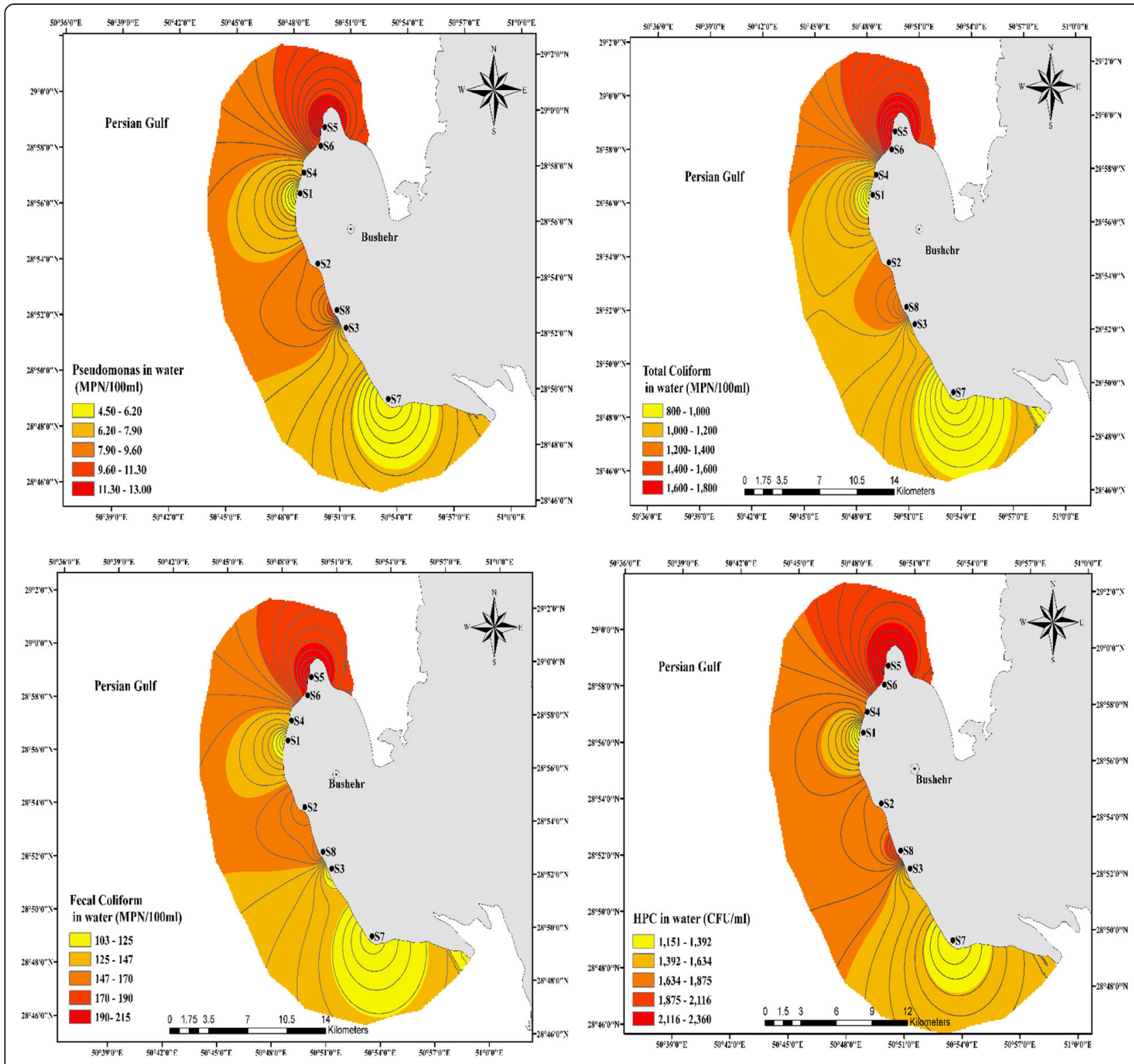

Fig. 2 The spatial distribution of bacterial organisms in seawater samples of Bushehr coastal areas 
24 hours. After drying, samples were sieved by shaker Heraeus device (Analysette 3PRO model), and a series of sieves including 4, 2, 1, 0.5, 0.25, 0.125 and $0.0625 \mathrm{~mm}$ which climbed on each other, respectively and a

Table 1 The mean, SD, minimum and maximum values of bacterial indicator levels in seawater samples at different stations (maximum values are expressed as bold italics; minimum values as bold underlined)

\begin{tabular}{|c|c|c|c|c|c|c|}
\hline $\begin{array}{l}\text { Indicator } \\
\text { bacteria }\end{array}$ & Station & $\mathrm{N}$ & Mean & $\begin{array}{l}\text { Std. } \\
\text { Deviation }\end{array}$ & Minimum & Maximum \\
\hline \multirow{8}{*}{$\begin{array}{l}\text { Total coliform } \\
\text { (MPN/100 ml) }\end{array}$} & 1 & 6 & 800 & 112.07 & 600 & 920 \\
\hline & 2 & 6 & 1220 & 184.93 & 920 & 1400 \\
\hline & 3 & 6 & 1000 & 161.12 & 680 & 1100 \\
\hline & 4 & 6 & 1050 & 168.99 & 750 & 1200 \\
\hline & 5 & 6 & 1800 & 328.00 & 1200 & 2200 \\
\hline & 6 & 6 & 1750 & 339.76 & 1100 & 2000 \\
\hline & 7 & 6 & 885 & 111.23 & 660 & 950 \\
\hline & 8 & 6 & 1400 & 247.54 & 920 & 1600 \\
\hline Average & & 48 & 1238.12 & 206.7 & 853.75 & 1421.25 \\
\hline \multirow{8}{*}{$\begin{array}{l}\text { Fecal coliform } \\
\text { (MPN/100 ml) }\end{array}$} & 1 & 6 & 103.67 & 15.57 & 79 & 120 \\
\hline & 2 & 6 & 165 & 8.07 & 160 & 180 \\
\hline & 3 & 6 & 111.17 & 17.11 & 94 & 140 \\
\hline & 4 & 6 & 143.33 & 20.15 & 110 & 170 \\
\hline & 5 & 6 & 213.33 & 72.67 & 110 & 330 \\
\hline & 6 & 6 & 193.33 & 43.29 & 140 & 260 \\
\hline & 7 & 6 & 107.17 & 16.29 & 79 & 130 \\
\hline & 8 & 6 & 170 & 38.14 & 110 & 230 \\
\hline Average & & 48 & 150.875 & 28.91125 & 110.25 & 195 \\
\hline \multirow{8}{*}{$\begin{array}{l}\text { Pseudomonas } \\
\text { (MPN/100 ml) }\end{array}$} & 1 & 6 & $\underline{4.50}$ & 1.22 & 3 & 6 \\
\hline & 2 & 6 & 8.50 & 2.07 & 5 & 11 \\
\hline & 3 & 6 & 6.33 & 2.16 & 3 & 9 \\
\hline & 4 & 6 & 7.33 & 2.58 & 4 & 11 \\
\hline & 5 & 6 & 13.00 & 2.28 & 11 & 17 \\
\hline & 6 & 6 & 11.00 & 1.414 & 9 & 13 \\
\hline & 7 & 6 & 4.83 & 1.169 & 3 & 6 \\
\hline & 8 & 6 & 10.33 & 1.966 & 7 & 12 \\
\hline Average & & 48 & 8.227 & 1.857 & 5.625 & 10.625 \\
\hline \multirow[t]{8}{*}{ HPC (CFU/ml) } & 1 & 6 & 1150.00 & 89.443 & 1000 & 1250 \\
\hline & 2 & 6 & 1841.67 & 724.166 & 1100 & 2800 \\
\hline & 3 & 6 & 1350.00 & 420.095 & 940 & 1850 \\
\hline & 4 & 6 & 1743.33 & 406.776 & 1350 & 2500 \\
\hline & 5 & 6 & 2358.33 & 941.497 & 1500 & 3500 \\
\hline & 6 & 6 & 2173.33 & 344.770 & 1890 & 2700 \\
\hline & 7 & 6 & 1248.33 & 217.754 & 970 & 1610 \\
\hline & 8 & 6 & 2078.33 & 302.815 & 1640 & 2400 \\
\hline Average & & 48 & 1742.91 & 430.914 & 1298.75 & 2326.25 \\
\hline
\end{tabular}

container were placed under them (for weight the particles smaller than $0.0625 \mathrm{~mm}$ ). Each sample was kept on device for 15 minutes. After that the sediment remaining on each sieve, and sediments of the lower container, weighed carefully with an accuracy of $0.1 \mathrm{mg}$. By multiplying the weight of each sieve in 4, the percent of its grain size was obtained. Finally as a percentage of dry matter in the sediment, have been reported in 4 different ranges (coarse sand $(>500 \mu \mathrm{m})$, medium sand $(500-250 \mu \mathrm{m})$, fine sand $(250-125 \mu \mathrm{m})$, mud $(<125 \mu \mathrm{m}))$. So the dominant group determined the types of grain size.

\section{Data analysis}

Statistical processing of data was done by using the SPSS version 20 (IBM Corp., USA). The normality of

Table 2 The mean, SD, minimum and maximum values of temperature, $\mathrm{pH}$ and salinity in seawater samples at various stations (maximum values are expressed as bold italics; minimum values as bold underlined)

\begin{tabular}{|c|c|c|c|c|c|c|}
\hline & Station & $N$ & Mean & $\begin{array}{l}\text { Std. } \\
\text { Deviation }\end{array}$ & Minimum & Maximum \\
\hline \multirow[t]{8}{*}{ Temperature $\left({ }^{\circ} \mathrm{C}\right)$} & 1 & 6 & 31.83 & 0.637 & 31.04 & 32.62 \\
\hline & 2 & 6 & 32.00 & 0.515 & 31.34 & 32.66 \\
\hline & 3 & 6 & 32.00 & 0.860 & 31.02 & 33.01 \\
\hline & 4 & 6 & 32.48 & 0.805 & 31.62 & 33.38 \\
\hline & 5 & 6 & 32.17 & 0.696 & 31.38 & 32.96 \\
\hline & 6 & 6 & 31.83 & 0.422 & 31.04 & 32.62 \\
\hline & 7 & 6 & 32.50 & 0.698 & 31.46 & 33.16 \\
\hline & 8 & 6 & $\underline{31.50}$ & 0.724 & 30.93 & 32.07 \\
\hline Average & & 48 & 32.04 & 0.67 & 31.23 & 32.81 \\
\hline \multirow[t]{8}{*}{$\mathrm{pH}$} & 1 & 6 & 8.38 & 0.423 & 7.79 & 8.88 \\
\hline & 2 & 6 & 8.35 & 0.187 & 8.10 & 8.60 \\
\hline & 3 & 6 & $\underline{8.16}$ & 0.037 & 8.10 & 8.20 \\
\hline & 4 & 6 & 8.26 & 0.071 & 8.20 & 8.40 \\
\hline & 5 & 6 & 8.41 & 0.330 & 7.74 & 8.60 \\
\hline & 6 & 6 & 8.21 & 0.117 & 7.99 & 8.30 \\
\hline & 7 & 6 & 8.48 & 0.179 & 8.23 & 8.71 \\
\hline & 8 & 6 & 8.23 & 0.267 & 7.89 & 8.71 \\
\hline Average & & 48 & 8.227 & 0.201 & 8.01 & 8.55 \\
\hline \multirow[t]{8}{*}{ Salinity (ppt) } & 1 & 6 & 37 & 0.648 & 36.2 & 38 \\
\hline & 2 & 6 & 30.1 & 1.859 & 28.7 & 33.6 \\
\hline & 3 & 6 & 35.1 & 1.334 & 33.2 & 36.5 \\
\hline & 4 & 6 & 32.4 & 1.545 & 31.1 & 35.4 \\
\hline & 5 & 6 & $\underline{27.7}$ & 2.126 & 24.2 & 29.9 \\
\hline & 6 & 6 & 28.9 & 1.898 & 25.3 & 30.4 \\
\hline & 7 & 6 & 35.6 & 2.459 & 32.1 & 37.6 \\
\hline & 8 & 6 & 29.6 & 1.283 & 28.2 & 31.5 \\
\hline Average & & 48 & 32.05 & 1.644 & 29.875 & 34.112 \\
\hline
\end{tabular}


data was checked by the Shapiro-Wilk test before analyzing. Descriptive statistics were applied for presentation of total coliform, fecal coliform, Pseudomonas aeruginosa as well as HPC concentration levels in seawater and sediment samples. Parametric Pearson test was applied to establish correlations between association of sediment and seawater characteristics and concentration levels of indicator bacteria. ArcMap 10.2 Geographical Information System (GIS) (ESRI, Redlands, CA) was also used as an appropriate tool for mapping and kriging interpolations of the bacterial concentration levels.

\section{Result and discussion}

\section{Seawater}

\section{Number of bacterial indicators}

The concentration levels of bacterial indicators in seawater samples of Bushehr coastal areas are presented in Fig. 2 and related data is summarized in Table 1. The average numbers of bacterial indicators including total coliform, fecal coliform, and Pseudomonas aeruginosa as well as HPC in seawater samples were
1238.13, 150.87, 8.22 MPN/100 ml and 1742.91 CFU/ml, respectively.

The highest average numbers of bacterial indicators in seawater samples between all stations were found in S5 and S6, which were the samples collected from the Solh-Abad and Jabari fishing ports with more frequent anthropogenic activities. Hamilton et al. have previously reported that pollutants from anthropogenic -influenced sources may carry diverse bacteria into the beaches and seawaters [37]. These cited fishing ports were also close to the pisciculture and aquaculture zones for fish and shellfish. Fish and shellfish are effective filter feeders and concentrate high levels of aquatic microorganisms such as fecal coliform and other bacteria in their bodies and may be built up to contents serious to human health. Most incidents of fecal contamination of aquaculture areas are ascribed to anthropogenic origins of such as illegal discharges from boats, inadequately maintained septic systems and run-off from farms [36]. Due to such risks to human health, it is proposed that all fishing ports with high concentration levels of
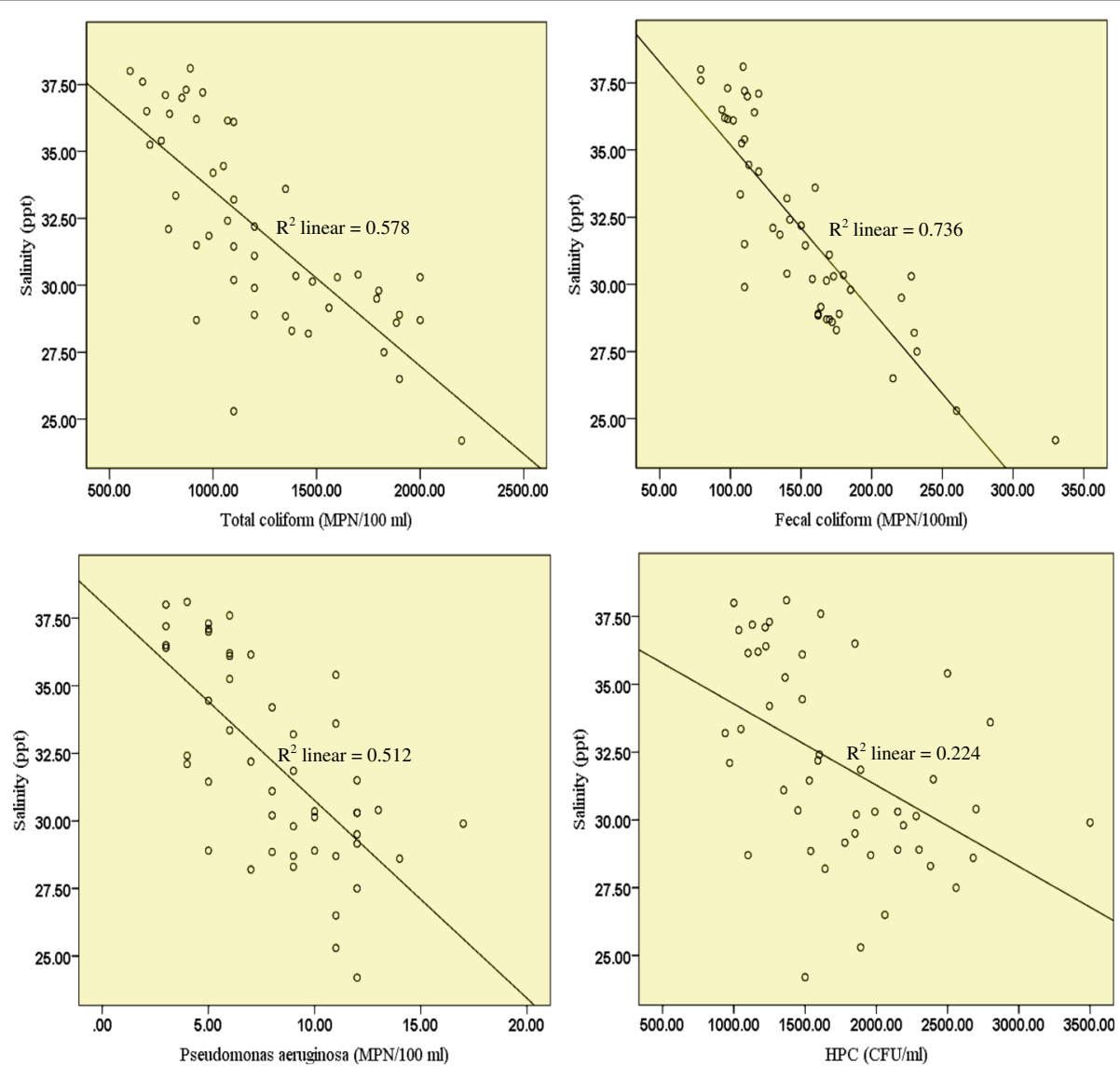

Fig. 3 Pearson correlation between the levels of all examined indicator organisms and salinity of seawater samples 
indicators bacteria (like these two stations in Bushehr coastal area) rigidly monitored and categorized by individual state health authorities. Generally, ports 'approved' for fishing must not exceed particular amounts of contamination, especially threshold values of fecal coliforms.

In addition to above mentioned two stations, one of the highest average numbers of bacterial indicators was found in S8 with an average levels of 1400, 170, $10.33 \mathrm{MPN} / 100 \mathrm{ml}$ and $2078.33 \mathrm{CFU} / \mathrm{ml}$ for total coliform, fecal coliform, Pseudomonas aeruginosa, as well as HPC respectively. This station is located in coastal area of the Shoghab Park, which is facing wide variety anthropogenic sources such as swimmers feces, throwing up garbage via tourisms, domestic wastewater treatment and disposal practices that may lead to the entrance of high levels of coliform bacteria and enteric human pathogens into the seawater. This area is also frequently utilized for recreational applications such a swimming, recreational fishing and recreational boating. Fecal pollution at swimming marine area can be dangerous to human health because feces may comprise bacteria, viruses and protozoa and there is possibility of feeding by swimmers which leads to various diseases [1].

\section{Physical and chemical factors}

The physical and chemical characteristics of seawater samples from the eight stations were determined and the maximum, minimum, mean and standard deviation values are presented in Table 2. The results of physical parameter measurements in seawater samples showed that these parameters are not tangible changed at different stations. The mean values of temperature and $\mathrm{pH}$ in seawater samples were in the range of $31.5-32.5^{\circ} \mathrm{C}$ and $8.16-8.41$ respectively. The salinity in seawater samples was in the range between 27.7 and 37 ppt. Pearson analysis showed that there was a significant inverse correlation between the concentrations levels of total coliforms, fecal coliforms, and Pseudomonas aeruginosa and salinity of seawater samples, and a weak inverse correlation between
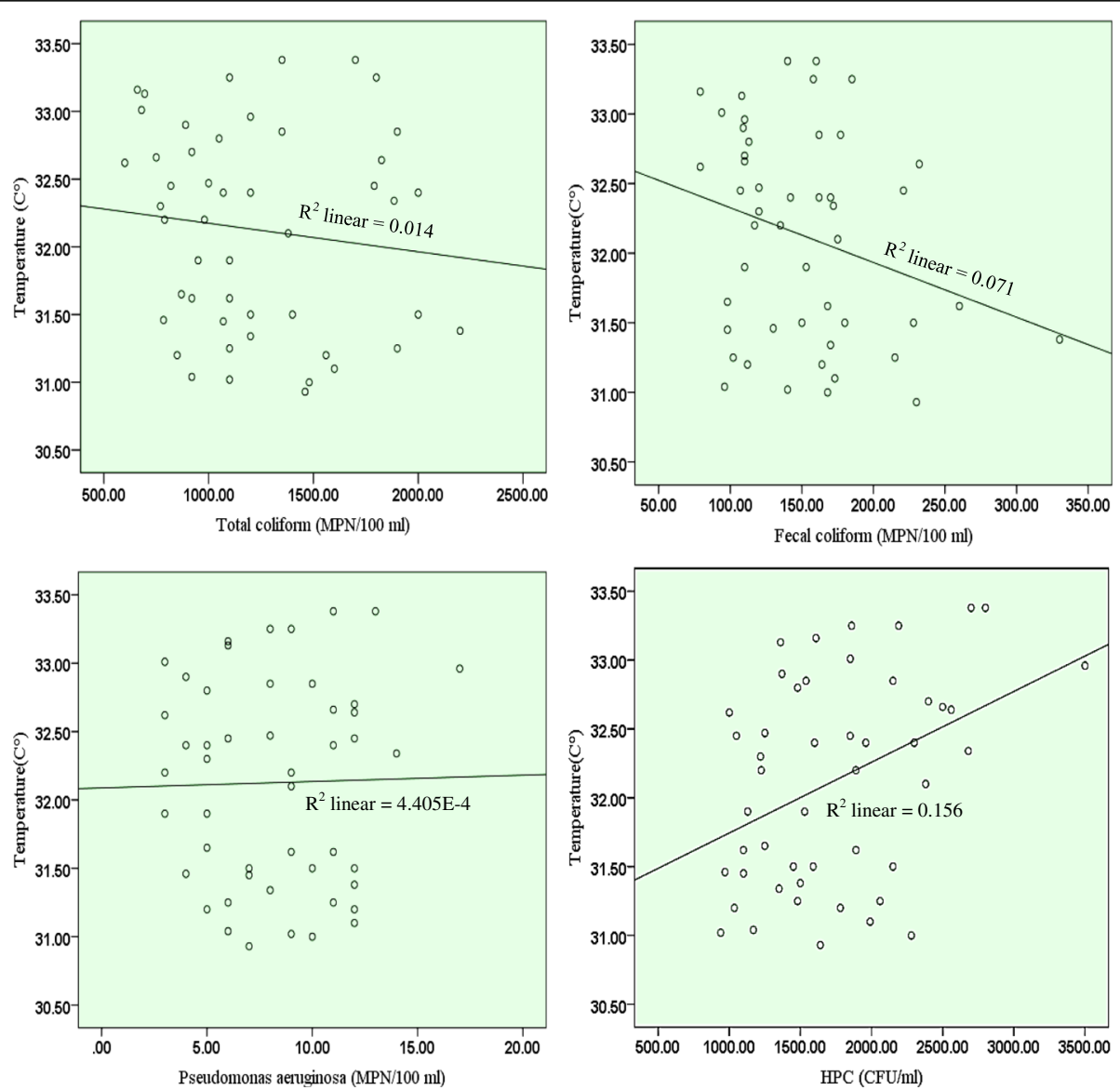

Fig. 4 Pearson correlation between the concentrations of all examined indicator bacteria and temperature of seawater samples 
salinity and HPC bacteria (Fig. 3). Therefore, the data revealed that with decreasing salinity, there was a corresponding increase in the values of indicator bacteria in seawater samples. A negative effect of salinity is attributed to specific characteristics of sea water, such as osmotic pressure and the toxicity of inorganic salts [38]. Most studies showed a negative correlation between values of indicator bacteria and salinity. For example, Rozen and Belkini found a reverse correlation between the level of $E$. coli and water salinity in seawater [39]. An inverse correlation between survival of $E$. coli and salinity of water has also been demonstrated by Anderson et al. [40]. In contrast to our studies, Jozić et al showed that there was no statistically significant effect of salinity on the E. coli bacteria [41]. Also Pearson analysis showed there were no statistically significant correlations between temperature and $\mathrm{pH}$ parameters and indicator organisms (Fig. 4 and Fig. 5). Similarly, Guyal et al. found that the indicator organisms (total coliforms, fecal coliforms, and salmonellae) were no statistically significant relationships with temperature, $\mathrm{pH}$, turbidity, and suspended solids contents of seawater [42].
In another study, Shibata et al. reported that except total coliform, there were no statistically significant relationships between the concentrations levels of enterococci, Escherichia coli, fecal coliform, and C. perfringens and physical-chemical parameters (rainfall, temperature, $\mathrm{pH}$, and salinity) [43]. But Blaustein et al. [44] and Sampson et al. [45] found that temperature was a major factor in the survival of E. coli in surface waters. In another study Placha et al. reported that the survival of Salmonella typhimurium and indicator bacteria (coliform and faecal coliform bacteria and faecal streptococci) was considerably affected by temperature [46].

\section{Sediment}

\section{Number of bacterial indicators}

The concentration levels of bacterial indicators in sediment samples of Bushehr coastal are given in Fig. 6 and associated data is summarized in Table 3. The mean log values of bacterial indicators between eight stations at various depths were compared and are shown in Fig. 7.
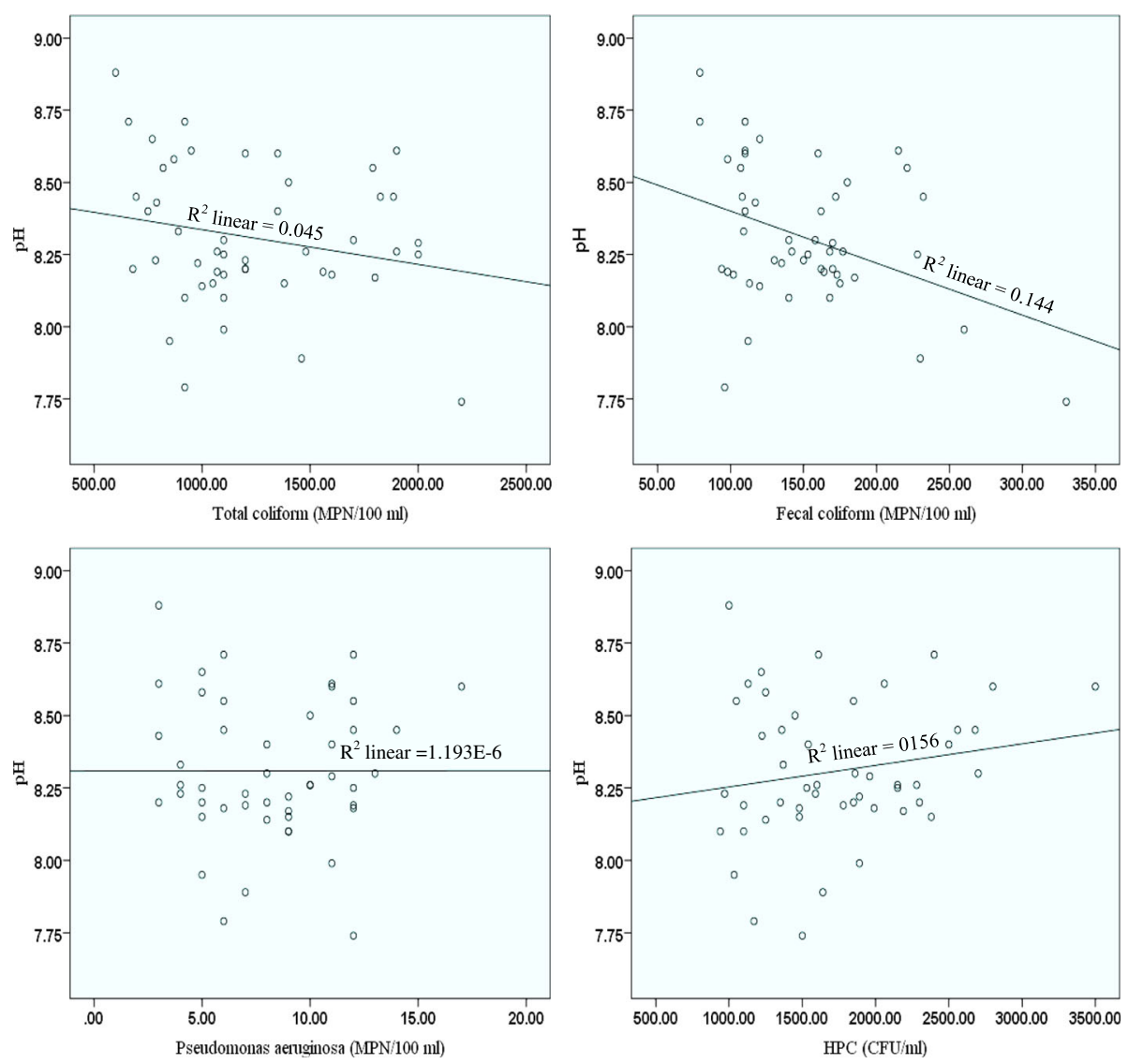

Fig. 5 Pearson correlation between the concentrations of all examined indicator bacteria and pH of seawater samples 


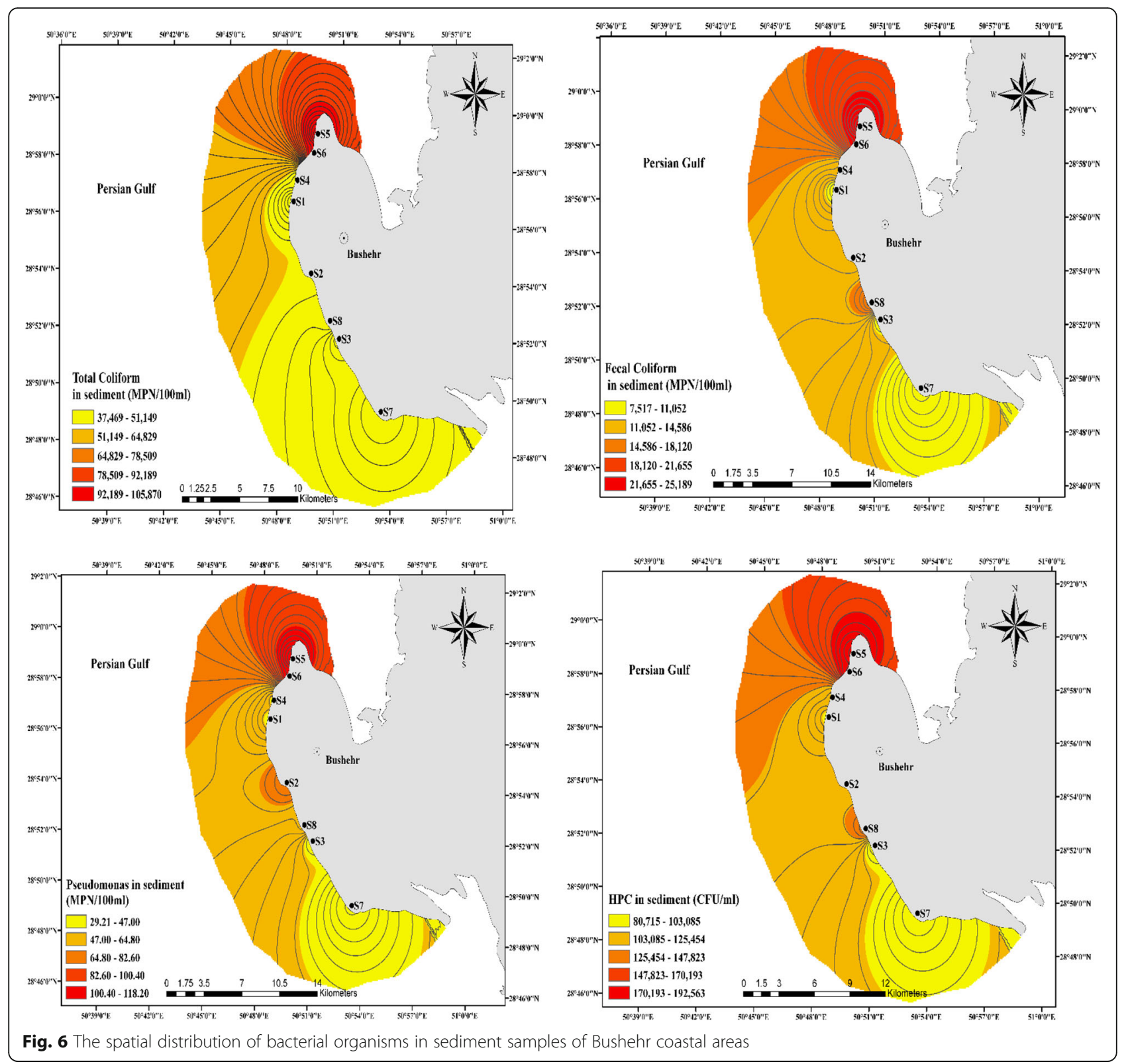

As seen in Table 3, the levels of total coliforms, fecal coliform, pseudomonas aeruginosa as well as HPC in sediment samples at different depths (from $0-20 \mathrm{~cm}$ ) in stations ( 1 to 8 ) varied between $25 \times 10^{3}$ and $51.67 \times 10^{3}$, $5.63 \times 10^{3}$ and $12.46 \times 10^{3}, 17.33$ and $65,36 \times 10^{3}$ and $147.5 \times 10^{3}$ respectively. The indicators bacteria counts at S5 and S6 sites, (hereinafter termed as the polluted sites) were considerably greater than those at the other six sites. It is also possible that the types of nutrients present in two stations are different from other stations and are more easily utilized by indicators bacteria. The ecological occurrence of indicators organisms in coastal area sediment has been documented [1, 43, 47]. In our study like many former studies [14, 23, 40], the numbers of indicator organisms in all examined sampling sites were higher for sediment samples compare to seawater samples. This may be due to the fact that sediments probably serve as a suitable environment for bacterial survival [48]. In present work, indicator bacteria were 10 to 100 times higher in sediments than in seawater samples. Crabill et al. reported that the average counts of fecal coliforms in sediment samples were 2200 times higher than the water counts [49]. In another research by Davies and Bavor, they confirmed that sediments may 
Table 3 The mean, SD, minimum and maximum values of bacterial indicators levels in various stations at different depths of sediment (maximum values are expressed as bold italics; minimum values as bold underlined)

\begin{tabular}{|c|c|c|c|c|c|c|c|c|c|}
\hline & Depth $(\mathrm{cm})$ & Station 1 & Station 2 & Station 3 & Station 4 & Station 5 & Station 6 & Station 7 & Station 8 \\
\hline \multirow{7}{*}{$\begin{array}{l}\text { Total coliform } \\
\text { (MPN/100 ml) }\end{array}$} & 0 & $51.67 \times 10^{3}$ & $75.83 \times 10^{3}$ & $52.17 \times 10^{3}$ & $71.67 \times 10^{3}$ & $138.33 \times 10^{3}$ & $131.67 \times 10^{3}$ & $52.17 \times 10^{3}$ & $75.83 \times 10^{3}$ \\
\hline & 4 & $46 \times 10^{3}$ & $65.66 \times 10^{3}$ & $45.33 \times 10^{3}$ & $60.5 \times 10^{3}$ & $125.67 \times 10^{3}$ & $118.33 \times 10^{3}$ & $44.5 \times 10^{3}$ & $62.83 \times 10^{3}$ \\
\hline & 7 & $38.83 \times 10^{3}$ & $56.17 \times 10^{3}$ & $41.33 \times 10^{3}$ & $52.16 \times 10^{3}$ & $107.17 \times 10^{3}$ & $102 \times 10^{3}$ & $40.83 \times 10^{3}$ & $56.83 \times 10^{3}$ \\
\hline & 10 & $34.17 \times 10^{3}$ & $46.33 \times 10^{3}$ & $36.83 \times 10^{3}$ & $43.17 \times 10^{3}$ & $93.5 \times 10^{3}$ & $86.5 \times 10^{3}$ & $36.33 \times 10^{3}$ & $48.5 \times 10^{3}$ \\
\hline & 15 & $29 \times 10^{3}$ & $34 \times 10^{3}$ & $29.33 \times 10^{3}$ & $30.33 \times 10^{3}$ & $89.66 \times 10^{3}$ & $76 \times 10^{3}$ & $29 \times 10^{3}$ & $33 \times 10^{3}$ \\
\hline & 20 & $25 \times 10^{3}$ & $25.33 \times 10^{3}$ & $25.67 \times 10^{3}$ & $22 \times 10^{3}$ & $81 \times 10^{3}$ & $67.66 \times 10^{3}$ & $25 \times 10^{3}$ & $26 \times 10^{3}$ \\
\hline & Average & $37.44 \times 10^{3}$ & $50.55 \times 10^{3}$ & $38.44 \times 10^{3}$ & $46.63 \times 10^{3}$ & $105.88 \times 10^{3}$ & $97.02 \times 10^{3}$ & $37.97 \times 10^{3}$ & $50.5 \times 10^{3}$ \\
\hline \multirow{7}{*}{$\begin{array}{l}\text { Fecal coliform } \\
\text { (MPN/100 ml) }\end{array}$} & 0 & $12.46 \times 10^{3}$ & $18.66 \times 10^{3}$ & $13.73 \times 10^{3}$ & $20.16 \times 10^{3}$ & $31 \times 10^{3}$ & $27.17 \times 10^{3}$ & $11.23 \times 10^{3}$ & $25.66 \times 10^{3}$ \\
\hline & 4 & $11.33 \times 10^{3}$ & $17.16 \times 10^{3}$ & $11.9 \times 10^{3}$ & $17.66 \times 10^{3}$ & $29.33 \times 10^{3}$ & $24.66 \times 10^{3}$ & $9.8 \times 10^{3}$ & $22.33 \times 10^{3}$ \\
\hline & 7 & $10.21 \times 10^{3}$ & $14.66 \times 10^{3}$ & $10.8 \times 10^{3}$ & $15.73 \times 10^{3}$ & $26.83 \times 10^{3}$ & $23 \times 10^{3}$ & $8.2 \times 10^{3}$ & $19.67 \times 10^{3}$ \\
\hline & 10 & $9.26 \times 10^{3}$ & $11.33 \times 10^{3}$ & $9.56 \times 10^{3}$ & $12.86 \times 10^{3}$ & $24 \times 10^{3}$ & $21.67 \times 10^{3}$ & $7.2 \times 10^{3}$ & $17.7 \times 10^{3}$ \\
\hline & 15 & 6.76 & $10.5 \times 10^{3}$ & $6.83 \times 10^{3}$ & $6.83 \times 10^{3}$ & $21.67 \times 10^{3}$ & $20 \times 10^{3}$ & $5.26 \times 10^{3}$ & $10.8 \times 10^{3}$ \\
\hline & 20 & $\underline{5.63 \times 10^{3}}$ & $8.66 \times 10^{3}$ & $\underline{5.26 \times 10^{3}}$ & $\underline{5.26 \times 10^{3}}$ & $\underline{18.33 \times 10^{3}}$ & $17.33 \times 10^{3}$ & $\underline{3.76 \times 10^{3}}$ & $\underline{9 \times 10^{3}}$ \\
\hline & Average & $9.28 \times 10^{3}$ & $13.5 \times 10^{3}$ & $9.68 \times 10^{3}$ & $13.09 \times 10^{3}$ & $25.19 \times 10^{3}$ & $22.3 \times 10^{3}$ & $7.52 \times 10^{3}$ & $17.42 \times 10^{3}$ \\
\hline \multirow{7}{*}{$\begin{array}{l}\text { Pseudomonas } \\
\text { (MPN/100 ml) }\end{array}$} & 0 & 65 & 108.83 & 62.6 & 73.5 & 160 & 156.6 & 39.5 & 87.6 \\
\hline & 4 & 58.83 & 97 & 52.3 & 62.3 & 135 & 125 & 37 & 72.6 \\
\hline & 7 & 57.33 & 82.6 & 47.6 & 51.5 & 122.3 & 108 & 33.16 & 66.3 \\
\hline & 10 & 46.1 & 70.8 & 40.5 & 43.3 & 104.5 & 91.6 & 27.6 & 57.16 \\
\hline & 15 & 22 & 42.6 & 23.66 & 24 & 101 & 84 & 22 & 27 \\
\hline & 20 & $\underline{17.33}$ & $\underline{29.3}$ & $\underline{18.6}$ & 17.33 & 86.33 & $\underline{73}$ & $\underline{16}$ & $\underline{20.6}$ \\
\hline & Average & 44.43 & 71.85 & 40.88 & 45.32 & 118.19 & 106.36 & 29.21 & 62.13 \\
\hline \multirow{7}{*}{$\begin{array}{l}\mathrm{HPC} \\
(\mathrm{CFU} / \mathrm{ml})\end{array}$} & 0 & $147.5 \times 10^{3}$ & $159.42 \times 10^{3}$ & $131.67 \times 10^{3}$ & $148.35 \times 10^{3}$ & $224.83 \times 10^{3}$ & $230.66 \times 10^{3}$ & $110.5 \times 10^{3}$ & $176.83 \times 10^{3}$ \\
\hline & 4 & $132.5 \times 10^{3}$ & $148 \times 10^{3}$ & $117.33 \times 10^{3}$ & $138 \times 10^{3}$ & $210.17 \times 10^{3}$ & $204.67 \times 10^{3}$ & $102.8 \times 10^{3}$ & $167.33 \times 10^{3}$ \\
\hline & 7 & $119.42 \times 10^{3}$ & $135.5 \times 10^{3}$ & $104.17 \times 10^{3}$ & $126.17 \times 10^{3}$ & $199.83 \times 10^{3}$ & $194.5 \times 10^{3}$ & $95.62 \times 10^{3}$ & $161.17 \times 10^{3}$ \\
\hline & 10 & $109.63 \times 10^{3}$ & $119.92 \times 10^{3}$ & $88.83 \times 10^{3}$ & $117.83 \times 10^{3}$ & $186 \times 10^{3}$ & $180.67 \times 10^{3}$ & $89.04 \times 10^{3}$ & $147.17 \times 10^{3}$ \\
\hline & 15 & $50.33 \times 10^{3}$ & $96.33 \times 10^{3}$ & $53 \times 10^{3}$ & $78.66 \times 10^{3}$ & $175 \times 10^{3}$ & $161.67 \times 10^{3}$ & $50.33 \times 10^{3}$ & $98.33 \times 10^{3}$ \\
\hline & 20 & $\underline{36 \times 10^{3}}$ & $\underline{80.67 \times 10^{3}}$ & $\underline{40 \times 10^{3}}$ & $\underline{67.66 \times 10^{3}}$ & $\underline{159.67 \times 10^{3}}$ & $\underline{149 \times 10^{3}}$ & $\underline{36 \times 10^{3}}$ & $\underline{90.33 \times 10^{3}}$ \\
\hline & Average & $99.23 \times 10^{3}$ & $123.3 \times 10^{3}$ & $89.17 \times 10^{3}$ & $112.78 \times 10^{3}$ & $192.58 \times 10^{3}$ & $186.86 \times 10^{3}$ & $80.71 \times 10^{3}$ & $140.19 \times 10^{3}$ \\
\hline
\end{tabular}

have 10 to 10,000 times higher amounts of fecal indicator organisms compare with the overlying seawater [22]. This may be due to the adsorption and sedimentation tend to remove organisms from suspension and concentrate them in bottom sediments [39]. But many studies reviewed by Pachepsky and Shelton [25], Brinkmeyer et al. [26] reported no correlations between indicators bacteria in the water column and underlying sediments.

\section{The general decay of indicators number in sediment}

Our results showed that the concentration levels of bacterial indicators decreased with depth (Table 4). This may be due to the death and inactivation of bacteria with depth. Because sediments is a natural filter that ensnares environmental particulates, organic substance and microorganisms [50, 51]. Our study are in accordance with former studies reported by Brinkmeyer et al. [26], Alm et al. [1], Haller et al. [21], and Pachepsky and Shelton [25].

As shown in Fig. 8, general decay pattern for examined bacterial indicators in sediments of Bushehr coastal areas are presented. These pattern can be useful to anticipate indicator bacteria numbers in marine environment sediments considering sediment texture and grain size. The highest percent decline of total coliform was found in depth between 0 and $4 \mathrm{~cm}$, but the highest percent decline of fecal coliform, Pseudomonas aeruginosa and HPC bacteria were found in depth between 10 and $15 \mathrm{~cm}$ (Fig. 9). Haller et al. found that the concentration levels of bacterial indicators decreased with depth. They 


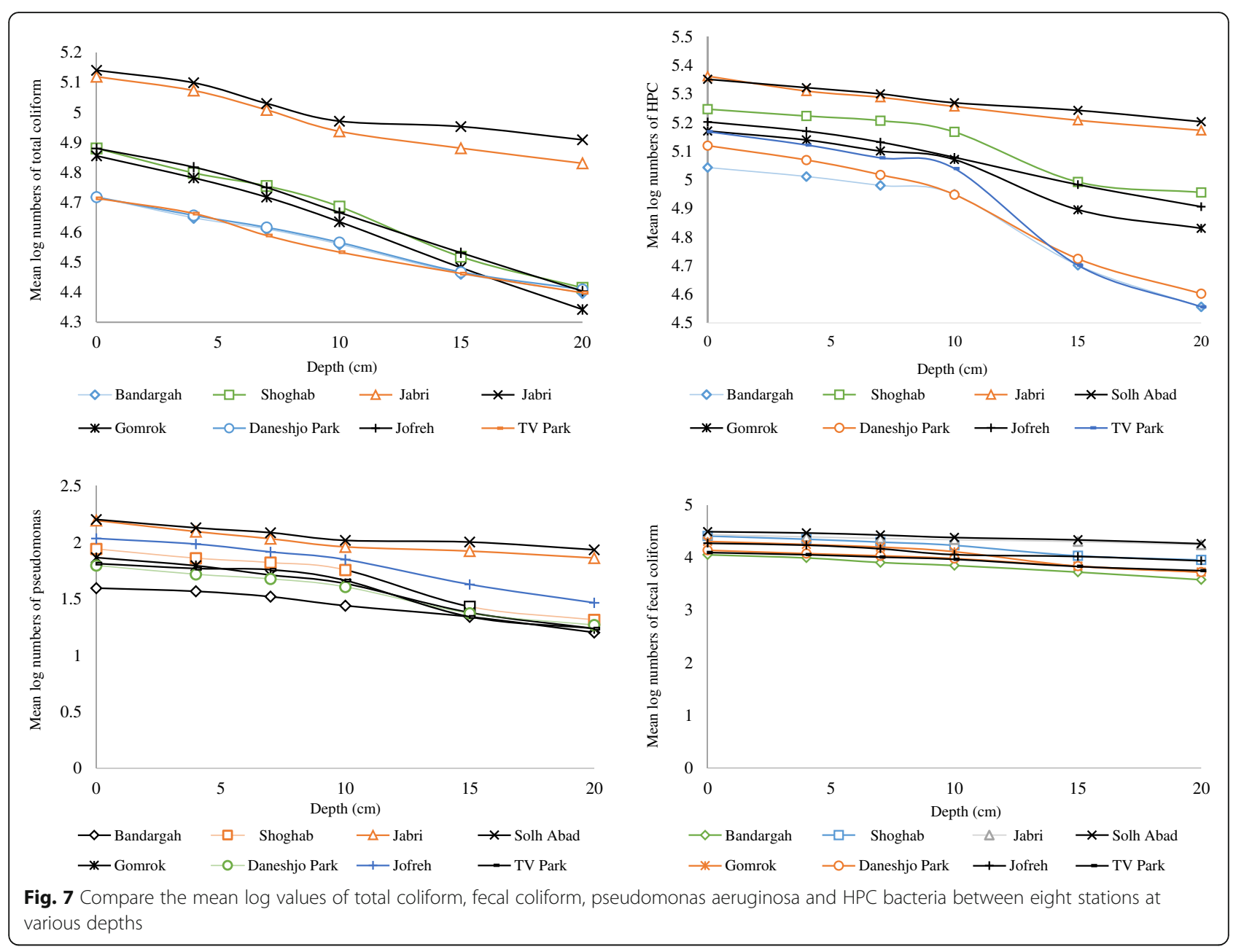

reported this can be due to decrease in organic matter content, they found out that organic matter content in the sediments samples reduced with depth, from $25 \%$ at $0-2 \mathrm{~cm}$ to $15 \%$ at $10 \mathrm{~cm}$ depth [21]. Brinkmeyer et al. detected a considerable reduction in the contents of indicator bacteria from the top $1 \mathrm{~cm}\left(10^{4}\right.$ to $\left.10^{5}\right)$ to the deeper 15,30 , and $60 \mathrm{~cm}$ horizons $\left(10^{2}\right.$ to $\left.10^{3}\right)$ [26].

\section{Grain size analysis}

Sediment grain size analysis in Bushehr coastal areas along the Persian Gulf are shown in Table 5. As seen, sediments in five stations (Skele-Jofreh (S2), Gomrok (S4), Skele-Solh Abad (S5), Skele-Jabri (S6), and Shoghab (S8)) have a texture of silt - clay (mud) and a diameter less than $125 \mu \mathrm{m}$, but sediments in three stations (TV Park (S1), Daneshjo Park (S3), and Bandargah (S7)), have a texture of fine sand and a diameter between 125-250 $\mu \mathrm{m}$. Our results revealed that the concentrations of indicators organisms were greater in muddy sediments compare with sandy ones. It is a fact that fine-grained sediment due to the higher surface area to volume ratio has more potential to tend higher concentration levels of bacterial indicators [52-54]. In a study by Lang and Smith, it was concluded that the clay amount of soils is particularly important regarding to abundance of indicator bacteria, as clay particles protected bacteria against predators and higher availability of substrates and moisture than sand particles [55]. A higher level of E. coli in sites with higher percent of clay and silt and lower sand has been reported in former studies $[56,57]$. Burton et al. found that $E$. coli survival was higher in sediments containing at least $25 \%$ clay (particles less than $2 \mathrm{~mm}$ in diameter), presumably due to enhanced attachment to the finer sediment particles [58]. In contrast to our study, Cinotto et al. reported that $E$. coli survival was higher in sediments with mainly big particles (ranging in size from 125 to $500 \mathrm{~mm}$ ), possibly due to bigger sediment particles facilitate increased permeability and accessibility of nutrients [59]. 
Table 4 Mean concentration levels and mean log numbers of indicators bacteria (the average of eight stations) in sediment samples at various depths

\begin{tabular}{|c|c|c|c|c|c|c|c|}
\hline Depth (cm) & & $\mathrm{N}$ & Mean & Log number & Std. Deviation & Minimum & Maximum \\
\hline \multirow{6}{*}{$\begin{array}{l}\text { Total coliform } \\
\text { (MPN/100 ml) }\end{array}$} & 0 & 48 & $81.17 \times 10^{3}$ & 4.909 & $34.65 \times 10^{3}$ & $43 \times 10^{3}$ & $180 \times 10^{3}$ \\
\hline & 4 & 48 & $71.34 \times 10^{3}$ & 4.853 & $32.58 \times 10^{3}$ & $34 \times 10^{3}$ & $170 \times 10^{3}$ \\
\hline & 7 & 48 & $61.92 \times 10^{3}$ & 4.792 & $27.54 \times 10^{3}$ & $33 \times 10^{3}$ & $140 \times 10^{3}$ \\
\hline & 10 & 48 & $53.17 \times 10^{3}$ & 4.725 & $23.99 \times 10^{3}$ & $31 \times 10^{3}$ & $130 \times 10^{3}$ \\
\hline & 15 & 48 & $43.78 \times 10^{3}$ & 4.641 & $25.32 \times 10^{3}$ & $26 \times 10^{3}$ & $120 \times 10^{3}$ \\
\hline & 20 & 48 & $37.21 \times 10^{3}$ & 4.571 & $23.76 \times 10^{3}$ & $21 \times 10^{3}$ & $110 \times 10^{3}$ \\
\hline \multirow{6}{*}{$\begin{array}{l}\text { Fecal coliform } \\
\text { (MPN/100 ml) }\end{array}$} & 0 & 48 & $20 \times 10^{3}$ & 4.301 & $8.17 \times 10^{3}$ & $9 \times 10^{3}$ & $35 \times 10^{3}$ \\
\hline & 4 & 48 & $18 \times 10^{3}$ & 4.255 & $7.68 \times 10^{3}$ & $7.9 \times 10^{3}$ & $33 \times 10^{3}$ \\
\hline & 7 & 48 & $16.1 \times 10^{3}$ & 4.207 & $7.189 \times 10^{3}$ & $6.3 \times 10^{3}$ & $31 \times 10^{3}$ \\
\hline & 10 & 48 & $14.1 \times 10^{3}$ & 4.149 & $6.77 \times 10^{3}$ & $4.9 \times 10^{3}$ & $27 \times 10^{3}$ \\
\hline & 15 & 48 & $11.08 \times 10^{3}$ & 4.044 & $6.18 \times 10^{3}$ & $4.6 \times 10^{3}$ & $22 \times 10^{3}$ \\
\hline & 20 & 48 & $9.16 \times 10^{3}$ & 3.961 & $5.59 \times 10^{3}$ & $3.1 \times 10^{3}$ & $21 \times 10^{3}$ \\
\hline \multirow{6}{*}{$\begin{array}{l}\text { Pseudomonas } \\
\text { (MPN/100 ml) }\end{array}$} & 0 & 48 & 94.23 & 1.974 & 49.656 & 26 & 240 \\
\hline & 4 & 48 & 80.02 & 1.903 & 38.793 & 23 & 180 \\
\hline & 7 & 48 & 71.13 & 1.852 & 34.742 & 22 & 170 \\
\hline & 10 & 48 & 60.23 & 1.779 & 29.826 & 21 & 140 \\
\hline & 15 & 48 & 43.29 & 1.636 & 31.403 & 17 & 130 \\
\hline & 20 & 48 & 34.83 & 1.541 & 27.864 & 14 & 110 \\
\hline \multirow{6}{*}{$\begin{array}{l}\mathrm{HPC} \\
\text { (CFU/ml) }\end{array}$} & 0 & 48 & $166.2 \times 10^{3}$ & 5.220 & $51.39 \times 10^{3}$ & $83 \times 10^{3}$ & $35 \times 10^{3}$ \\
\hline & 4 & 48 & $152.6 \times 10^{3}$ & 5.183 & $45.32 \times 10^{3}$ & $76 \times 10^{3}$ & $241 \times 10^{3}$ \\
\hline & 7 & 48 & $142 \times 10^{3}$ & 5.152 & $45.48 \times 10^{3}$ & $65 \times 10^{3}$ & $232 \times 10^{3}$ \\
\hline & 10 & 48 & $129.8 \times 10^{3}$ & 5.113 & $44.38 \times 10^{3}$ & $56 \times 10^{3}$ & $199 \times 10^{3}$ \\
\hline & 15 & 48 & $95.4 \times 10^{3}$ & 4.979 & $47.34 \times 10^{3}$ & $43 \times 10^{3}$ & $182 \times 10^{3}$ \\
\hline & 20 & 48 & $82.4 \times 10^{3}$ & 4.916 & $47.62 \times 10^{3}$ & $26 \times 10^{3}$ & $172 \times 10^{3}$ \\
\hline
\end{tabular}

\section{Conclusion}

The present study was the first attempt to survey indicators bacteria profiles in seawater and sediment of coastal area along the Persian Gulf. Our study revealed that there was a reverse correlation between the levels of indicator bacteria and salinity of seawater samples. The levels of indicator organisms were 10 to 100 times higher in sediments than in seawater samples. The concentration levels of indicators bacteria were higher in muddy sediments compare with sandy

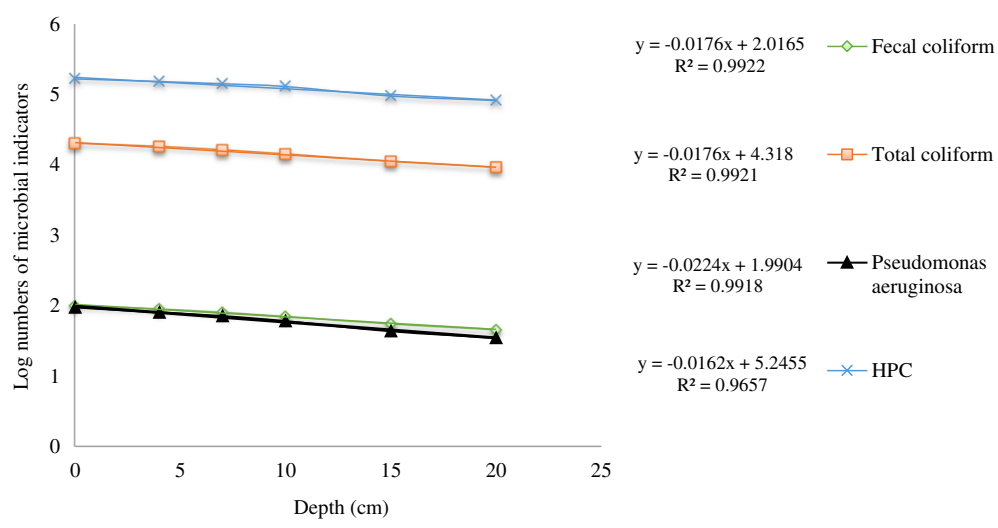

Fig. 8 General decay pattern for the microbial indicators in marine sediment 


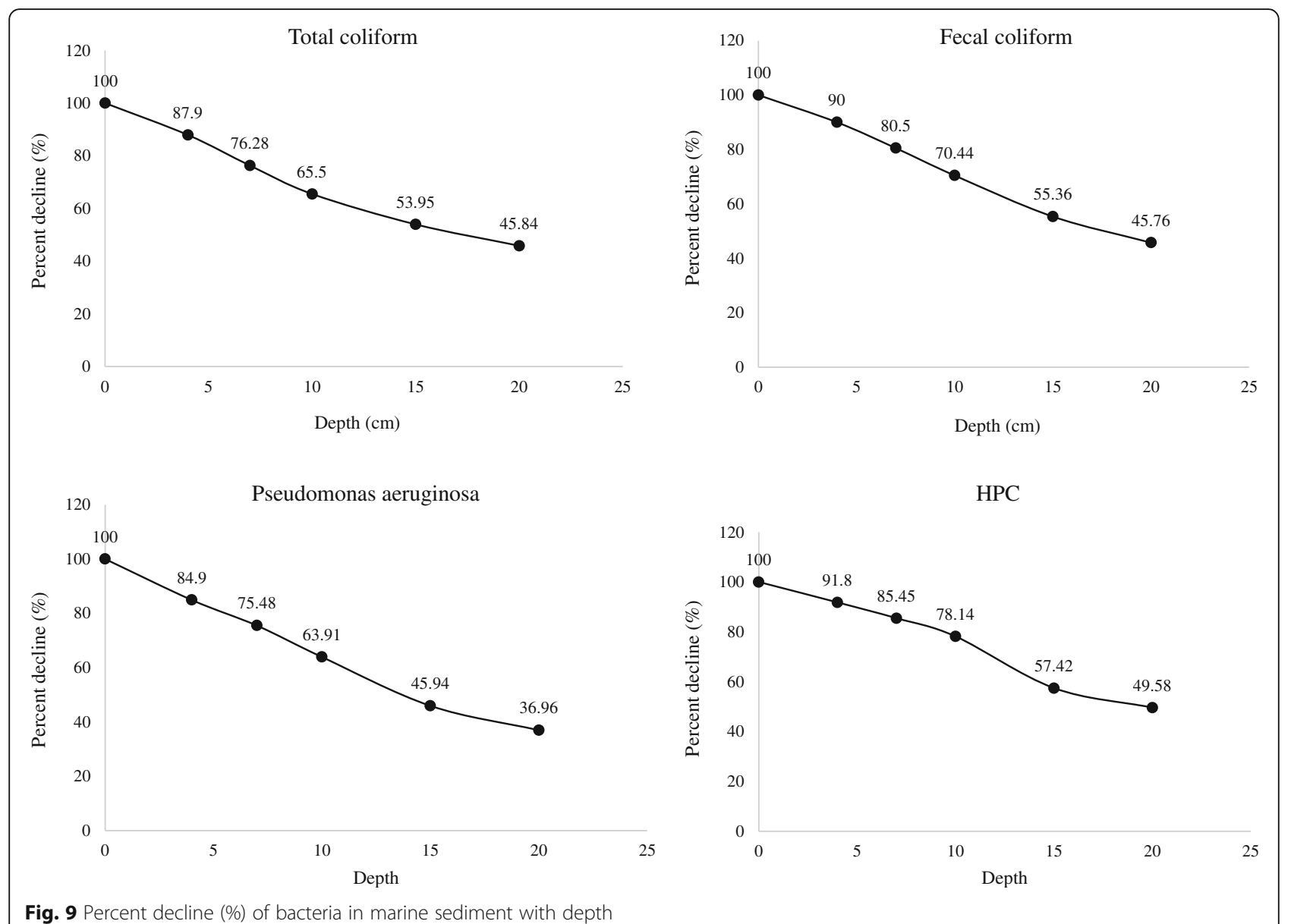

ones. Our results revealed that the concentration levels of bacterial indicators decreased with depth. Our presented models in this study can be useful models to anticipate indicator bacteria numbers in marine environment sediments considering sediment texture and grain size. The orders of indicator bacteria numbers in seawater and sediment samples were
$\mathrm{HPC}>$ total coliform $>$ fecal coliform $>$ pseudomonas aeruginosa. The concentration levels of indicator bacteria in sampling stations showed that coastal areas along the Persian Gulf are facing a wide variety of anthropogenic sources. Finally monitoring and mitigation measures of marine environment particularly in places with entertainments uses are greatly suggested.

Table 5 Sediment grain size analysis in Bushehr port coasts at various stations

\begin{tabular}{llllllllll}
\hline Station & \multicolumn{1}{l}{ Mesh $(\mathrm{mm})$} & \multicolumn{1}{c}{ Texture } \\
\cline { 2 - 8 } & 4 & 2 & 1 & 0.5 & 0.25 & 0.125 & 0.063 & $<0.063$ & \\
\hline 1 & 0.934 & 3.728 & 5.756 & 8.938 & 35.327 & 38.158 & 6.794 & 0.437 & Fine sand \\
2 & 0.283 & 1.412 & 1.226 & 3.796 & 8.443 & 29.172 & 53.848 & 1.820 & Silt - clay \\
3 & 1.110 & 4.084 & 4.809 & 10.844 & 16.576 & 42.916 & 14.540 & 5.120 & Fine sand \\
4 & 6.892 & 3.325 & 2.697 & 2.196 & 2.777 & 18.742 & 58.756 & 4.613 & Silt - clay \\
5 & 1.418 & 1.141 & 0.710 & 0.411 & 0.729 & 31.861 & 64.316 & 0.740 & Silt - clay \\
6 & 0.568 & 0.561 & 1.02 & 1.694 & 4.372 & 21.813 & 67.44 & 2.525 & Silt - clay \\
7 & 0.221 & 0.132 & 0.676 & 10.328 & 17.910 & 37.431 & 30.254 & 3.046 & Fine sand \\
8 & 0 & 0.242 & 0.418 & 0.951 & 4.716 & 39.661 & 51.831 & 2.18 & Silt - clay \\
\hline
\end{tabular}




\section{Abbreviations}

GIS: Geographical Information System; HPC: Heterotrophic Plate Count

\section{Acknowledgements}

The authors are grateful to the Bushehr University of Medical Sciences for their financial support. This project was partly supported by Iran National Science Foundation (Research Chair Award No. 95/INSF/44913)

\section{Funding}

This study was performed as a master thesis in Environmental Health Engineering founded by Bushehr University of Medical Science.

\section{Availability of data and materials}

Additional data from the study are available by request to the corresponding author by email.

\section{Authors' contributions}

VNK was the main investigator, collected the samples and data, and wrote the first draft of the manuscript. SD was the supervisor of study in all steps, edited and polished the final version of manuscript. IN has guided this manuscript. $\mathrm{AO}$ performed the statistical analysis. AV and HA were advisors of the study. RM, MK, FFG and FK conducted the experiments. All authors read and approved the final version of manuscript.

\section{Competing interests}

The authors declare that they have no competing interests.

\section{Consent for publication}

"Not applicable"

\section{Ethics approval and consent to participate}

"Not applicable"

\section{Author details}

${ }^{1}$ Department of Environmental Health Engineering, Faculty of Health, Bushehr University of Medical Sciences, Bushehr, Iran. ${ }^{2}$ The Persian Gulf Marine Biotechnology Research Center, The Persian Gulf Biomedical Sciences Research Institute, Bushehr University of Medical Sciences, Boostan 19 Alley, Imam Khomeini Street, Bushehr, Iran. ${ }^{3}$ Systems Environmental Health, Oil, Gas and Energy Research Center, The Persian Gulf Biomedical Sciences Research Institute, Bushehr University of Medical Sciences, Bushehr, Iran. ${ }^{4}$ The Persian Gulf Tropical Medicine Research Center, The Persian Gulf Biomedical Sciences Research Institute, Bushehr University of Medical Sciences, Bushehr, Iran. ${ }^{5}$ Environmental Health Department, School of Public Health, Iran University of Medical Sciences, Tehran, Iran. ${ }^{6}$ The Persian Gulf Studies and Researches Center Marine Biotechnology Department, Persian Gulf University, Bushehr, Iran.

\section{Received: 29 October 2016 Accepted: 7 February 2017} Published online: 10 March 2017

\section{References}

1. Alm EW, Burke J, Spain A. Fecal indicator bacteria are abundant in wet sand at freshwater beaches. Water Res. 2003;37(16):3978-82

2. Gerba CP. Assessment of enteric pathogen shedding by bathers during recreational activity and its impact on water quality. Quant Microbiol. 2000; 2(1):55-68.

3. Lee SH, Levy DA, Craun GF, Beach MJ, Calderon RL. Surveillance for waterborne-disease outbreaks-United States, 1999-2000. MMWR Surveill Summ (Washington, DC: 2002), 2002; 51(8): 1-47

4. Wade TJ, Pai N, Eisenberg JN, Colford Jr JM. Do US Environmental Protection Agency water quality guidelines for recreational waters prevent gastrointestinal illness? A systematic review and meta-analysis. Environ Health Perspect. 2003;111(8):1102

5. Feng P, Weagant SD, Grant MA, Burkhardt W, Shellfish M, Water B. BAM: Enumeration of Escherichia coli and the Coliform Bacteria. Bacteriological analytical manual. 2002;13-19.

6. United States Environmental Protection Agency. The National Seawater Quality Inventory, EPA-841-R-02-001.USEPA Office of Seawater, Washington, DC. USA: Environmental Protection Agency; 2002.
7. Carter JT, Rice EW, Buchberger SG, Lee Y. Relationships between levels of heterotrophic bacteria and water quality parameters in a drinking water distribution system. Water Res. 2000;34(5):1495-502.

8. Donovan E, Unice K, Roberts JD, Harris M, Finley B. Risk of gastrointestinal disease associated with exposure to pathogens in the water of the Lower Passaic River. Appl Environ Microbiol. 2008;74(4):994-1003.

9. Shuval H. Estimating the global burden of thalassogenic diseases: human infectious diseases caused by wastewater pollution of the marine environment. J Water Health. 2003;1(2):53-64.

10. Colford Jr JM, Wade TJ, Schiff KC, Wright CC, Griffith JF, Sandhu SK, Burns S, Sobsey M, Lovelace G, Weisberg SB. Water quality indicators and the risk of illness at beaches with nonpoint sources of fecal contamination. Epidemiology. 2007;18(1):27-35.

11. Fleisher JM, Fleming LE, Solo-Gabriele HM, Kish JK, Sinigalliano CD, Plano L, Elmir SM, Wang JD, Withum K, Shibata T, Gidley ML. The BEACHES Study: health effects and exposures from non-point source microbial contaminants in subtropical recreational marine waters. Int J Epidemiol. 2010;39(5):1291-8.

12. Benham BL, Baffaut C, Zeckoski RW, Mankin KR, Pachepsky YA, Sadeghi AM, Brannan KM, Soupir ML, Habersack MJ. Modeling bacteria fate and transport in watersheds to support TMDLs. Biol Eng Trans. 2006;49(4):987-1002.

13. Droppo IG, Krishnappan BG, Liss SN, Marvin C, Biberhofer J. Modelling sediment-microbial dynamics in the South Nation River, Ontario, Canada: Towards the prediction of aquatic and human health risk. Water Res. 2011; 45(12):3797-809.

14. Rehmann CR, Soupir ML. Importance of interactions between the water column and the sediment for microbial concentrations in streams. Water Res. 2009:43(18):4579-89.

15. Cho KH, Pachepsky YA, Kim JH, Guber AK, Shelton DR, Rowland R. Release of Escherichia coli from the bottom sediment in a first-order creek: Experiment and reach-specific modeling. J Hydrol (Amst). 2010;391(3):322-32.

16. Jamieson RC, Joy DM, Lee H, Kostaschuk R, Gordon RJ. Resuspension of Sediment-Associated in a Natural Stream. J Environ Qual. 2005;34(12):581-9.

17. Koirala SR, Gentry RW, Perfect E, Schwartz JS, Sayler GS. Temporal variation and persistence of bacteria in streams. J Environ Qual. 2008:37(4):1559-66.

18. Decamp O, Warren A. Investigation of Escherichia coli removal in various designs of subsurface flow wetlands used for wastewater treatment. Ecol Eng. 2000;14(3):293-9.

19. Droppo IG. Structural controls on floc strength and transport. Can J Civ Eng. 2004;31(4):569-78.

20. Droppo IG, King K, Tirado SM, Sousa A, Wolfaardt G, Liss SN, Warren LA Assessing riverine sediment-pathogen dynamics: implications for the management of aquatic and human health risk. IAHS-AISH publication. 2010; $245-250$

21. Haller L, Poté J, Loizeau JL, Wildi W. Distribution and survival of faecal indicator bacteria in the sediments of the Bay of Vidy, Lake Geneva, Switzerland. Ecol Indic. 2009;9(3):540-7.

22. Davies $\mathrm{CM}$, Bavor $\mathrm{HJ}$. The fate of stormwater-associated bacteria in constructed wetland and water pollution control pond systems. J Appl Microbiol. 2000:89(2):349-60.

23. Smith J, Edwards J, Hilger H, Steck TR. Sediment can be a reservoir for coliform bacteria released into streams. J Gen Appl Microbiol. 2008:54:173-9.

24. Byappanahalli MN, Nevers MB, Korajkic A, Staley ZR, Harwood VJ. Enterococci in the environment. Microbiol Rev. 2012;76(4):685-706.

25. Pachepsky YA, Shelton DR. Escherichia coli and fecal coliforms in freshwater and estuarine sediments. Crit Rev Environ Sci Technol. 2011:41(12):1067-110.

26. Brinkmeyer R, Amon RM, Schwarz JR, Saxton T, Roberts D, Harrison S, Ellis N, Fox J, DiGuardi K, Hochman M, Duan S. Distribution and persistence of Escherichia coli and Enterococci in stream bed and bank sediments from two urban streams in Houston, TX. Sci Total Environ. 2015;502:650-8.

27. Obiri-Danso K, Jones $K$. Intertidal sediments as reservoirs for hippurate negative campylobacters, salmonellae and faecal indicators in three EU recognised bathing waters in North West England. Water Res. 2000;34(2):519-27.

28. Arfaeinia H, Nabipour I, Ostovar A, Asadgol Z, Abuee E, Keshtkar M, Dobaradaran S. Assessment of sediment quality based on acid-volatile sulfide and simultaneously extracted metals in heavily industrialized area of Asaluyeh, Persian Gulf: concentrations, spatial distributions, and sediment bioavailability/toxicity. Environ Sci Pollut Res Int. 2016;9:1-20.

29. Dobaradaran S, Nabipour I, Saeedi R, Ostovar A, Khorsand M, Khajeahmadi N, Hayati R, Keshtkar M. Association of metals (Cd, Fe, As, $\mathrm{Ni}, \mathrm{Cu}, \mathrm{Zn}$ and $\mathrm{Mn}$ ) with cigarette butts in northern part of the Persian Gulf. Tob Control. 2016 
30. Nabipour I, Dobaradaran S. Fluoride and chloride levels in the Bushehr coastal seawater of the Persian Gulf. Fluoride. 2013;46(4):204-7.

31. Dobaradaran S, Abadi DR, Mahvi AH, Javid A. Fluoride in skin and muscle of two commercial species of fish harvested off the Bushehr shores of the Persian Gulf. Fluoride. 2011;44(3):143.

32. Dobaradaran S, Naddafi K, Nazmara S, Ghaedi H. Heavy metals (Cd, Cu, Ni and $\mathrm{Pb}$ ) content in two fish species of Persian Gulf in Bushehr Port, Iran. Afr J Biotechnol. 2013;9(37):6191-3.

33. Abadi DR, Dobaradaran S, Nabipour I, Lamani X, Ravanipour M, Tahmasebi R, Nazmara S. Comparative investigation of heavy metal, trace, and macro element contents in commercially valuable fish species harvested off from the Persian Gulf. Environ Sci Pollut Res Int. 2015;22(9):6670-8

34. ASTM. Standard Guide for Collection, Storage, Characterization, and Manipulation of Sediments for Toxicological Testing and for Selection of Samplers Used to Collect Benthic Invertebrates, Publ. E1391-03. Philadelphia: American Society for Testing and Materials; 2014

35. Gy P. Sampling of particulate materials theory and practice (Vol. 6). Elsevier. USA: CDC press; 2012.

36. Buchanan JB. Sediment analysis. In: Holme NA, McIntyre AD, editors. Methods for the Study of Marine Benthos. Oxford and Edinburgh.: Blackwell Scientific Publications; 1984. p. 41-65.

37. Hamilton MJ, Hadi AZ, Griffith JF, Ishii S, Sadowsky MJ. Large scale analysis of virulence genes in Escherichia coli strains isolated from Avalon Bay, CA. Water Res. 2010;44(18):5463-73.

38. Gauthier MJ, Munro PM. Mohajer S (1987) Influence of salts and sodium chloride on the recovery of Escherichia coli from seawater. Curr Microbiol. 1987;15(1):5-10

39. Rozen Y, Belkin S. Survival of enteric bacteria in seawater. FEMS Microbiol Rev. 2001;25(5):513-29.

40. Anderson KL, Whitlock JE, Harwood VJ. Persistence and differential survival of fecal indicator bacteria in subtropical waters and sediments. Appl Environ Microbiol. 2005;71(6):3041-8.

41. Šolić M, Krstulović N. Separate and combined effects of solar radiation, temperature, salinity and $\mathrm{pH}$ on the survival of faecal coliforms in seawater. Mar Pollut Bull. 1992;24(8):411-6.

42. Goyal SM, Gerba CP, Melnick JL. Occurrence and distribution of bacterial indicators and pathogens in canal communities along the Texas coast. Appl Environ Microbiol. 1977;34(2):139-49.

43. Shibata T, Solo-Gabriele HM, Fleming LE, Elmir S. Monitoring marine recreational water quality using multiple microbial indicators in an urban tropical environment. Water Res. 2004;38(13):3119-31.

44. Blaustein RA, Pachepsky Y, Hill RL, Shelton DR, Whelan G. Escherichia coli survival in waters: temperature dependence. Water Res. 2013;47(2): 569-78.

45. Sampson RW, Swiatnicki SA, Osinga VL, Supita JL, McDermott CM, Kleinheinz G. Effects of temperature and sand on E. coli survival in a northern lake water microcosm. J Water Health. 2006;4(3):389-93.

46. Placha I, Venglovský J, Sasakova N, Svoboda IF. The effect of summer and winter seasons on the survival of Salmonella typhimurium and indicator micro-organisms during the storage of solid fraction of pig slurry. J Appl Microbiol. 2001;91(6):1036-43.

47. Whitman RL, Shively DA, Pawlik H, Nevers MB, Byappanahalli MN Occurrence of Escherichia coli and enterococci in Cladophora (Chlorophyta) in nearshore water and beach sand of Lake Michigan. Appl Environ Microbiol. 2003;69:4714-9.

48. Jamieson RC, Joy DM, Lee H, Kostaschuk R, Gordon R. Transport and deposition of sediment-associated Escherichia coli in natural streams. Water Res. 2005;39(2):2665-75.

49. Crabill C, Donald R, Snelling J, Foust R, Southam G. The impact of sediment fecal coliform reservoirs on seasonal water quality in Oak Creek, Arizona. Water Res. 1999:33(9):2163-71.

50. Hijnen WAM, Schijven JF, Bonne P, Visser A, Medema GJ. Elimination of viruses, bacteria and protozoan oocysts by slow sand filtration. Water Sci Technol. 2004;50(1):147-54

51. Hua J, An P, Winter J, Gallert C. Elimination of COD, microorganisms and pharmaceuticals from sewage by trickling through sandy soil below leaking sewers. Water Res. 2003;37(18):4395-404.

52. Piorkowski GS, Jamieson RC, Hansen LT, Bezanson GS, Yost CK. Characterizing spatial structure of sediment E. coli populations to inform sampling design. Environ Monit Assess. 2014;186(1):277-91.
53. Brennan FP, O'Flaherty V, Kramers G, Grant J, Richards KG. Long-term persistence and leaching of Escherichia coli in temperate maritime soils. Appl Environ Microbiol. 2010;76(5):1449-55.

54. Bradford SA, Simunek J, Walker SL. Transport and straining of E. coli 0157: $\mathrm{H} 7$ in saturated porous media. Water Resour Res. 2006;42(12):1-12.

55. Lang NL, Smith SR. Influence of soil type, moisture content and biosolids application on the fate of Escherichia coli in agricultural soil under controlled laboratory conditions. J Appl Microbiol. 2007;103(6):2122-31.

56. Atwill ER, Lewis DJ, Bond RF, Pereira MD, Huerta M, Ogata SB. Protocol consideration for monitoring fecal coliform and in Northern California Estuaries. University of California, Davis School of Veterinary Medicine and University of California Cooperative Extension, Sonoma County, Santa Rosa, California. 2007

57. Craig DL, Fallowfield HJ, Cromar NJ. Use of microcosms to determine persistence of Escherichia coli in recreational coastal water and sediment and validation with in situ measurements. J Appl Microbiol. 2004;96(5):922-30.

58. Burton GA, Gunnison D, Lanza GR. Survival of pathogenic bacteria in various freshwater sediments. Appl Environ Microbiol. 1987;53(3):633-8.

59. Cinotto PJ. Occurrence of fecal-indicator bacteria and protocols for identification of fecal-contamination sources in selected reaches of the West Branch Brandywine Creek, Chester County, Pennsylvania. US Department of the Interior, US Geological Survey. 2005

\section{Submit your next manuscript to BioMed Central and we will help you at every step:}

- We accept pre-submission inquiries

- Our selector tool helps you to find the most relevant journal

- We provide round the clock customer support

- Convenient online submission

- Thorough peer review

- Inclusion in PubMed and all major indexing services

- Maximum visibility for your research

Submit your manuscript at www.biomedcentral.com/submit
) Biomed Central 